\title{
Burden on caregivers of patients with sequelae of cerebrovascular accident
}

\author{
Sobrecarga de cuidadores de pessoas com sequela de acidente vascular encefálico \\ Sobrecarga de cuidadores de personas con secuelas de accidente cerebrovascular
}

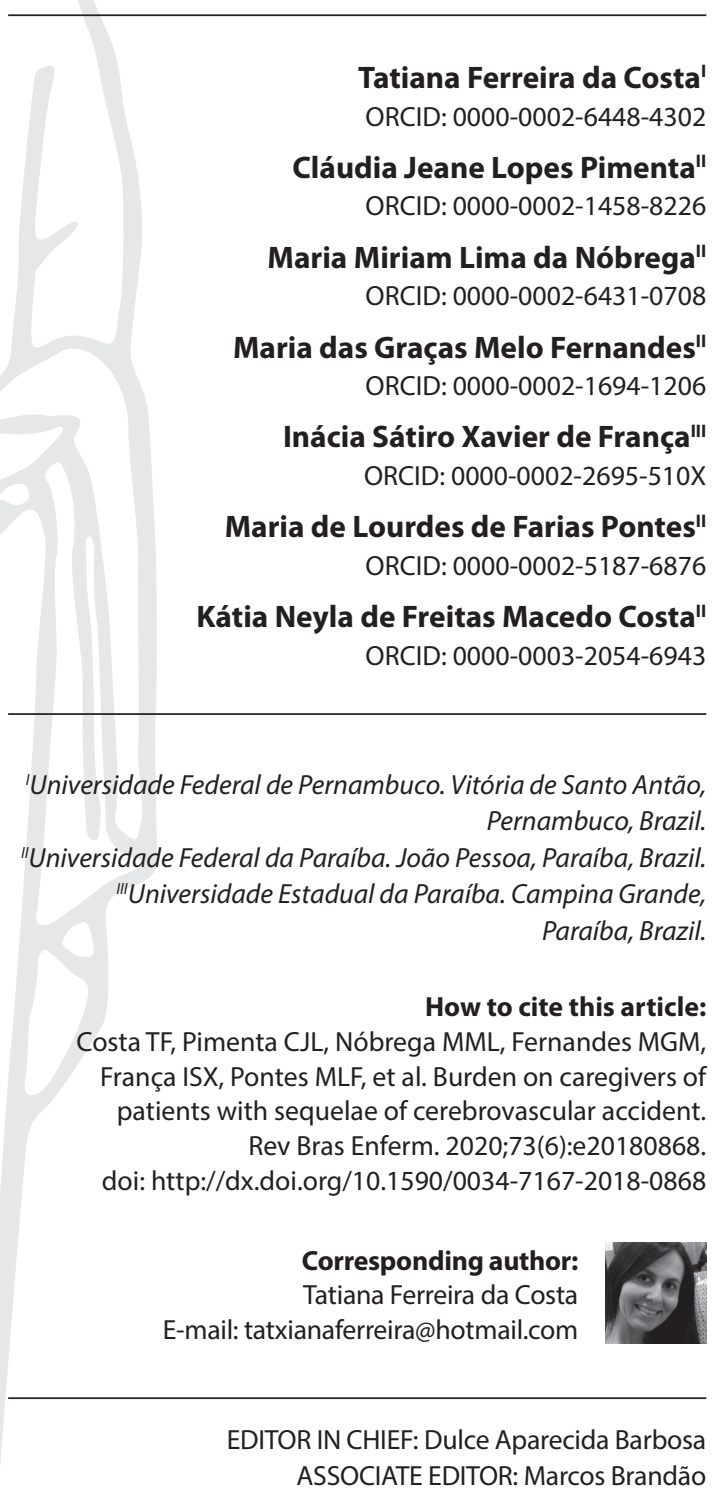

\begin{abstract}
Objectives: to evaluate the burden and its relationship with the sociodemographic characteristics of caregivers of people with sequelae of stroke. Methods: a cross-sectional, exploratory, and quantitative study was conducted with 151 caregivers of people with sequelae of stroke, through home interviews between September and December 2017. Results: there was a general mean of low burden. The items that indicated the worst changes were: "My time for social activities with friends," "My time for family activities," "My ability to cope with stress," and "My physical functioning."There was an association of burden with the female sex and with caregivers who have been assisting for longer. Conclusions: the results allow us to reflect on the need to create a policy aimed at family caregivers to reduce the impact of care delivery.

Descriptors: Caregivers; Stroke; Complications; Population Characteristics; Nursing.
\end{abstract}

\section{RESUMO}

Objetivos: avaliar a sobrecarga e sua relação com as características sociodemográficas de cuidadores de pessoas com sequela de acidente vascular encefálico. Métodos: pesquisa transversal, exploratória e quantitativa, realizada com 151 cuidadores de pessoas com sequela de acidente vascular encefálico, mediante entrevistas domiciliares entre setembro e dezembro de 2017. Resultados: verificou-se uma média geral de sobrecarga baixa. Os itens que indicaram piores mudanças foram: "Meu tempo para atividades sociais com amigos"; "Meu tempo para atividades da família"; "Minha capacidade de lidar com o estresse"; e "Meu funcionamento físico". Houve associação da sobrecarga com o sexo feminino e com cuidadores que cuidam a mais tempo. Conclusões: os resultados permitem refletir sobre a necessidade de criação de uma política voltada para os cuidadores familiares que vise à redução do impacto da prestação de cuidados.

Descritores: Cuidadores; Acidente Vascular Cerebral; Complicações; Características da População; Enfermagem.

\section{RESUMEN}

Objetivos: evaluar la sobrecarga y su relación con las características sociodemográficas de cuidadores de personas con secuela de Accidente Cerebrovascular. Métodos: investigación transversal, exploratoria y cuantitativa, realizada con 151 cuidadores de personas con secuela de Accidente Cerebrovascular, mediante entrevistas domiciliares entre septiembre y diciembre de 2017. Resultados: ha sido verificado una media general de sobrecarga baja. Los ítems que indicaron peores cambios han sido: "Mi tiempo para actividades sociales con amigos"; "Mi tiempo para actividades de la familia”; "Mi capacidad de resistir al estrés"; $y$ "Mi funcionamiento físico". Hubo asociación de la sobrecarga con el sexo femenino y con cuidadores que cuidan a más tiempo. Conclusiones: los resultados permiten reflexionar sobre la necesidad de creación de una política vuelta para los cuidadores familiares que propone a la reducción del impacto de la prestación de cuidados.

Descriptores: Cuidadores; Accidente Cerebrovascular; Complicaciones; Características de la Población; Enfermería. 


\section{INTRODUCTION}

Cerebrovascular accident (CVA) is a neurological syndrome resulting from a disorder in brain circulation that persists for more than 24 hours. It occurs due to the reduction or complete interruption of cerebral blood supply and can be classified into two types: ischemic or hemorrhagic ${ }^{(1)}$.

Epidemiological data show a high incidence of CVA. Worldwide, the occurrence of one case every five seconds is estimated, so it is the second cause of death and the first cause of disability ${ }^{(2)}$. A survey conducted in households in 2013 by the Instituto Brasileiro de Geografia e Estatística (Brazilian Institute of Geography and Statistics) showed that $25.5 \%$ of patients who had a stroke had severe limitations ${ }^{(3)}$.

After being discharged, those affected by the stroke are commonly dependent on the care of third parties, and in most situations, only one person, called the primary or informal caregiver, assumes responsibility for care ${ }^{(4)}$. Health professionals, other family members, and the patients themselves generally devalue the caregiver's role. This fact provokes mood variations in the caregiver and changes in the way of facing daily challenges, triggering different negative feelings experienced routinely, such as anger, fear, sadness, guilt, despair, loneliness and anguish, which results in psychological distress, sleep disorders and low situational self-esteem ${ }^{(5-6)}$.

The various tasks attributed to the caregiver added to the lack of support, the lack of preparation to care, the level of dependence of the patient, the chronicity of the disabling situation, the complexity of care activities, the worsening of health status and the uncertainty of the future, can generate burden, leading in many cases to social isolation, reduction or extinction of leisure activities, impairment of professional activity, loss of employment and lack of time to self-care ${ }^{(7-12)}$.

In a population-based study conducted in the municipality of Joao Pessoa-PB, a high rate of burden was evidenced (84.6\%) among caregivers of the elderly ${ }^{(13)}$. In another study conducted in the same municipality with caregivers of people with sequelae of stroke, the prevalence of burden was $77.2 \%{ }^{(14)}$. It is essential to highlight that experiencing a burden for a long time contributes to the emergence of tension and stress ${ }^{(12,15)}$.

The needs of caregivers are dynamic over time, which requires individualized attention and adaptations to improve their life significantly ${ }^{(5,16-17)}$. In this context, burden screening is essential to plan psychoeducational and psychotherapeutic interventions, to improve the formal support network and the ability of caregivers to face the situation in order to avoid or reduce tension and improve the quality of life of those involved ${ }^{(18-20)}$.

\section{OBJECTIVES}

To evaluate the burden and its relationship with the sociodemographic characteristics of caregivers of people with sequelae of stroke.

\section{METHODS}

\section{Ethical aspects}

The study was developed following the recommendations of Resolution 466/2012 of the National Health Council of Brazil, with approval by the Research Ethics Committee. We invited the caregivers to participate in the study by verbal invitation. They signed the Free and Informed Consent Form, being duly informed about the purpose of the research, its purpose, risks and benefits, procedures, and confidentiality of the information provided.

\section{Study Design, location, and period}

Cross-sectional and exploratory research, with a quantitative approach, carried out with caregivers of people with sequelae of stroke, registered in the Unidades de Saúde da Família (USF Family Health Units) of the city of João Pessoa, Paraíba, between September and December 2017. The STROBE instrument was used to guide the methodology of this study.

\section{Sample: inclusion and exclusion criteria}

The study population was composed of primary informal caregivers of people with sequelae of stroke. The sample calculation was based on the number of people affected by stroke who were registered in the USF of João Pessoa during 2016, totaling 249 individuals. The sample size was defined using the calculation for finite populations with known proportions, based on a margin of error of $5 \%$ (error $=0.05$ ), with a reliability degree of $95 \%\left(a=0.05\right.$, which provides $Z_{0.05 / 2}=1.96$ ), considering the true proportion as $50 \%(p=0.50)$ for the presence of sequelae, resulting in a sample of 151 caregivers.

The inclusion criteria: being 18 years old or older and a primary informal caregiver of patients with sequelae of stroke, registered in USF of João Pessoa-PB. The study excluded secondary or tertiary formal and informal caregivers and caregivers of patients who had sequelae of other health changes.

\section{Study Protocol}

Data were collected through individual interviews conducted in households. The USFs were randomly selected, and three were drawn from each health district. The identification of caregivers occurred through contact with the nurses of each unit, requesting information about the people who suffered a stroke and had some sequela. For data collection, a semi-structured instrument was used to obtain sociodemographic data containing questions related to the characteristics of caregivers (gender, education, monthly income and time of care) and the Bakas Caregiving Outcome Scale (BCOS) to assess the burden of caregivers of patients with sequelae of stroke.

BCOS has high sensitivity to detect changes in self-esteem and in financial, emotional, and social aspects that have occurred over time, and it has been widely used in other countries ${ }^{(21)}$. The cross-cultural adaptation of BCOS followed these steps: translation, back-translation; consolidation of the translated version; and semantic and content evaluation. After the adaptation of the scale, data were collected.

The original BCOS is a one-dimensional instrument that analyzes the changes that occurred throughout the life of the caregiver of these patients, being based on the concepts of social function, subjective well-being, and health. It was developed with 48 items; and, later, the brief version was defined with ten items ${ }^{(22)}$. In the current version, five items were included, totaling 15 items, measured on a 7-point response scale ("Changed for the worse" = -3 until "Changed for the best" $=+3$ ), in which the lower the score, the higher the burden ${ }^{(21)}$. 


\section{Results analysis and statistics}

We performed the reliability analysis of the adapted version of the BCOS by measuring the internal consistency of the items of the instrument, calculated by Cronbach's alpha coefficient. The value assigned to this measure ranges from 0 to 1 , and the higher the value, the greater the congruence between the items, indicating the scale homogeneity ${ }^{(23)}$. If deleting an item would increase to more than 0.1 from the total alpha of the domain, it would be deleted ${ }^{(24)}$. The Kolmogorov-Smirnov test was used to verify the normality of the numerical data. The association between BCOS and sociodemographic variables was performed using the Mann-Whitney test. The level of significance used for the statistical analysis was $5 \%(p \leq 0.05)$.

\section{RESULTS}

Among the 151 caregivers of patients with sequelae of stroke who participated in the study, the majority $(118 ; 78.1 \%)$ were female, between 56 and 65 years $(42 ; 27.8 \%)$, married or in a domestic partnership $(99 ; 65.6 \%)$, having 5 to 8 years of education ( 41 ; $27.2 \%)$, Catholic $(92 ; 60.9 \%)$, having an individual income of up to $\mathrm{R} \$ 880,00$ (67; 44.4\%), family income between $\mathrm{R} \$ 881.00$ and $\mathrm{R} \$$ $1760.00(63 ; 41.7 \%)$, had retirement benefits as the main income $(49 ; 32.5 \%)$ and did not consider the income sufficient $(88 ; 58.3 \%)$.

Table 1 - Means of BCOS items, João Pessoa, Paraíba, Brazil, 2017 ( $n=151$ )

\begin{tabular}{|c|c|c|}
\hline Items & Mean & $\begin{array}{l}\text { Standard } \\
\text { deviation }\end{array}$ \\
\hline $\begin{array}{l}\text { 1. My self-esteem (What I think about myself, my } \\
\text { emotions and my behaviors in life) }\end{array}$ & 3.26 & 1.354 \\
\hline $\begin{array}{l}\text { 2. My physical health (General condition of the body } \\
\text { concerning diseases and the physical capacity to } \\
\text { perform daily activities) }\end{array}$ & 3.02 & 1.191 \\
\hline 3. My time for family activities & 2.79 & 1.345 \\
\hline $\begin{array}{l}\text { 4. My ability to deal with stress (Situations that I } \\
\text { perceive as threatening) }\end{array}$ & 2.93 & 1.365 \\
\hline $\begin{array}{l}\text { 5. My relationship with friends (Affection, friendship, } \\
\text { love, loyalty, and protection) }\end{array}$ & 3.45 & 1.284 \\
\hline $\begin{array}{l}\text { 6. My vision of the future (Ability to make plans in the } \\
\text { near or distant future) }\end{array}$ & 3.67 & 1.389 \\
\hline $\begin{array}{l}\text { 7. My energy level (Willingness to carry out daily } \\
\text { activities) }\end{array}$ & 3.18 & 1.265 \\
\hline $\begin{array}{l}\text { 8. My emotional well-being (Thoughts of joy and } \\
\text { pleasure in everyday experiences) }\end{array}$ & 3.25 & 1.474 \\
\hline $\begin{array}{l}\text { 9. Social roles (Mother or father, sister, brother, friend, } \\
\text { daughter, son) }\end{array}$ & 3.72 & 1.293 \\
\hline 10. My time for social activities with friends & 2.77 & 1.344 \\
\hline $\begin{array}{l}\text { 11. My relationship with family (Affection, friendship, } \\
\text { love, loyalty, and protection) }\end{array}$ & 3.53 & 1.269 \\
\hline $\begin{array}{l}\text { 12. My financial stability (Organization of expenses, } \\
\text { control of money, expenses, savings) }\end{array}$ & 3.07 & 1.335 \\
\hline $\begin{array}{l}\text { 13. My relationship with the stroke survivor } \\
\text { (Affection, friendship, love, loyalty, and protection) }\end{array}$ & 4.00 & 1.596 \\
\hline $\begin{array}{l}\text { 14. My physical functioning (Muscle strength and } \\
\text { absence of body pain when performing daily activities) }\end{array}$ & 2.97 & 1.186 \\
\hline
\end{tabular}

Burden on caregivers of patients with sequelae of cerebrovascular accident Costa TF, Pimenta CJL, Nóbrega MML, Fernandes MGM, França ISX, Pontes MLF, et al.

Table 1 (concluded)

Items

Standard deviation

15. My general health (State of complete physical, mental and social well-being and not just the $3.03 \quad 1.143$ absence of disease)

Note: BCOS - Bakas Caregiving Outcome Scale.

Table 1 shows the assessment of the burden, with a low general mean(48.62) and also a low mean (below 4 = neutral value) for each item, which means that caregivers perceived negative changes as a result of the provision of care. The items that indicated the worst changes were: "My time for social activities with friends" (2.77); "My time for family activities" (2.79); "My ability to deal with stress" (Situations that I perceive as threatening) (2.93) and "My physical functioning" (My muscular strength, absence of body pain for daily activities) "(2.97). For reliability analysis, Cronbach's alpha of the scale was calculated, with a total value of 0.898 .

The association of BCOS with the following variables was evaluated to assess different groups of caregivers: gender, age, education, monthly income, and duration of caregiving. With regard to gender, it is possible to observe that the female caregivers $(3.17 \pm 0.89)$ have a greater burden than male caregivers $(3.49 \pm 0.60)$, with statistically significant results $(p=0.044)$. The duration of caregiving the caregiver has dedicated to the patient was associated $(p=0.008)$ with BCOS showing a greater burden among those who have cared for longer (Table 2).

Table 2 - BCOS association with gender, age, monthly income of caregivers and duration of caregiving, João Pessoa, Paraíba, Brazil, 2017 ( $n=151)$

\begin{tabular}{lcc}
\hline Variable & Mean (Standard Deviation) & $\boldsymbol{p}$ value \\
\hline $\begin{array}{l}\text { Gender } \\
\text { Male }\end{array}$ & $3.49(0.60)$ & \\
$\quad$ Female & $3.17(0.89)$ & 0.044 \\
Age & & \\
$\quad \leq 55$ years old & $3.26(0.79)$ & 0.897 \\
$\quad \geq 56$ years old & $3.21(0.91)$ & \\
Years of education & & \\
$\quad \leq 4$ years of study & $3.27(0.71)$ & 0.817 \\
$\geq 5$ years of study & $3.22(0.92)$ & \\
Monthly income & & \\
$\leq \mathrm{R} \$ 1,760$ & $3.22(0.80)$ & \\
$\geq \mathrm{R} \$ 1,761$ & $3.27(0.94)$ & \\
Duration of caregiving & & \\
$\quad \leq 2$ years & $3.50(0.79)$ & \\
$\quad \geq 3$ years & $3.10(0.85)$ & \\
\hline Note: BCOS - Bakas Caregiving Outcome Scale. &
\end{tabular}

\section{DISCUSSION}

The BCOS instrument assesses the burden of caregivers through changes in various aspects of life. The present study evidenced a general mean of 48.62, which shows a greater burden than that of patients with advanced cancer $^{(25)}$; and lower, compared to that of stroke victims with spasticity ${ }^{(26)}$. Regarding the items on the scale, except for the relationship with the care receiver, all others got worse after the stroke. The sudden occurrence of this disabling disease is associated with the lack of information and training, as well as the lack of attention from health professionals, 
resulting in facing an infinite number of unmet needs and which commonly affects all aspects of caregivers' lives ${ }^{(5)}$.

The first item that assesses self-esteem had a mean of 3.26. Self-esteem is an important characteristic, which provides effective adaptations of the individual in a stressful situation ${ }^{(27)}$. Due to the dedication to the patient, caregivers often do not prioritize actions that meet their personal needs. This fact, over time, causes damage in their lives, such as low self-esteem, which can affect different aspects of the caregiver's and patient's lives ${ }^{(28)}$. A longitudinal survey showed that self-esteem influences patient satisfaction when their health status worsens concerning their relationship with the caregiver ${ }^{(29)}$.

The items that assess physical aspects - physical health, energy level, and physical functioning - also obtained low means (3.02, 3.18 , and 2.97, respectively). Stroke is a disabling disease, which makes the individual dependent on almost all activities of daily living. The responsibilities and tasks usually fall on the primary caregiver, who starts to neglect his own health and, as a result, is affected by physical illnesses ${ }^{(5)}$. A survey carried out in Brazil, which evaluated the health-related quality of life of caregivers of stroke victims, showed an association between burden and the domains of physical capacity, vitality, and pain ${ }^{(14)}$.

The emotional aspects assessed by the items "ability to deal with stress,"'"emotional well-being," and "vision of the future" scored 2.93, 3.25 , and 3.67, respectively. Behavioral aspects and the presence of emotional changes, such as anxiety, depression, and changes in the patient's mood, are the primary triggers of the caregiver's emotional changes - for example, irritability, cognitive and emotional problems, depression, and anger. These feelings can result in exhaustion, with drastic consequences for the caregiver-patient relationship, such as maltreatment and institutionalization, since, without help in managing problematic behaviors, caregivers may become depressed and unable to care for the patient ${ }^{(30)}$.

A qualitative study showed that the emotional and physical well-being of caregivers of people with sequelae of stroke was impaired because of the uncertainty and unpredictability of the time of care, in addition to their expectations and misunderstood needs. The responsibility to care for other people was a factor that influenced the increase in tension ${ }^{(31)}$. The social changes evaluated by the items "time for activities with the family," "time for activities with the friends" and "social roles" obtained, respectively, the scores 2.79, 2.77 and 3.79, the lowest means, except for the item that assesses the change in social roles.

Studies that analyzed especially the initial period after discharge ${ }^{(32-33)}$ identified that caregivers felt they had no life of their own and no space to rest and prisoners in their own home, especially when they received little support and needed to perform other roles, such as formal work and home activities. They also felt sad, overwhelmed and guilty for not having enough strength to do everything ${ }^{(34)}$.

The responsibilities attributed to caregivers can limit their social life and leisure activities, which affects their well-being, the quality of care, as well as the patient's recovery and reintegration into society. Caregivers who receive more social support can manage their personal activities well, which is essential to continue performing their role $\mathrm{e}^{(35)}$.

The perception of change in financial life was assessed only by one item, which obtained a main of 3.07. The financial impact on the lives of caregivers is a common factor that causes stress, due to the expenses with the provision of care, with diapers, medical appointments, medications, rehabilitation therapies, and private transportation to take the patient to health units and hospitals. Also, they often need to leave their jobs, so they lose their income and become totally dependent on the financial support of other family members, who may fail to do so continuously(36).

The burden was assessed by comparing different groups of caregivers, which involved gender, age, income, education, and duration of caregiving. The result showed that only gender and time spent providing care were associated with BCOS. Female caregivers had the worst perception of the provision of care in relation to male caregivers, and those who had cared for longer also felt more burdened.

The results discussed in the literature are divergent about gender. However, most national and international studies have pointed out that female caregivers have more negative outcomes, namely: greater burden and psychological effects such as depression, anxiety, and stress ${ }^{(37-41)}$. This fact is due to the multiple activities attributed to women - taking care of children, doing housework, working outside the home, among others ${ }^{(40)}$. Besides, the male perception of less burden can be justified due to the coping mechanisms focused more on problem-solving and coping with stress than on emotions and escape ${ }^{(39)}$.

Age and monthly income did not show a statistically significant association with BCOS. However, other research shows that low income is associated with burden and contributes to impair the quality of life ${ }^{(14,42-44)}$. Generally, income is reduced due to the decrease in income from work and expenses resulting from the needs for the care of the dependent person ${ }^{(43)}$.

Low education level is also an essential factor, and, in most cases, it is related to low income, which results in financial losses that significantly burden the caregiver. That is because taking care of others suggests the provision of basic needs - namely, food, physical activities, and specific needs, such as the purchase of medication. Therefore, the limitation of financial resources can be translated as a source of stress for the caregiver ${ }^{(38)}$.

The higher level of education influences the strategies for coping with stress, with a consequent decrease in the perceived burden $^{(42)}$. Some authors also emphasize that the lack of knowledge and information about the act of caring, often linked to the low level of education, can trigger feelings of anxiety and anguish in the caregiver that negatively impact the care provided and the caregiver's health ${ }^{(45)}$. As a result, nurses must know the educational level of the caregiver and the patient so that they can transmit the information as clearly as possible.

Concerning age, some research reveals that younger caregivers are more burdened than older ones, which this study did not found. This founding is justified because, in many circumstances, they have to adjust their daily activities, which are also their competence, such as working, taking care of the home and children, with the care provided to the dependent person, and this causes an accumulation of roles ${ }^{(38)}$. However, the physical repercussions appear to be higher in caregivers of older age, as shown by a study conducted in Brazil, in which older caregivers had the worst HRQoL in the domains of functional capacity and pain ${ }^{(14)}$.

The duration of caregiving was associated with BCOS and exhibited a greater burden on those who had cared for longer. A 
study conducted in China, which aimed to analyze the experience of caregivers over six months, found that the burden was slightly reduced over time, but the symptoms of depression remained stable $^{(46)}$. The perception of stressors seems to be higher at the beginning of the event; however, physiologically, there is a more significant stress response over time, as shown in a longitudinal survey ${ }^{(47)}$. This fact may be due to poorly adaptive responses to stress.

\section{Study limitations}

The limitations of the study were related to the investigation of primary informal caregivers population only, which can restrict the understanding of the burden of care provided for stroke victims. The allusions for future research through the application of the scale in other populations of caregivers and different care contexts can be promising so that the construct can be better understood, and the care situation better evaluated.

\section{Contributions to nursing, health or public policy}

This study has implications at the governmental level, in the sense of raising complacent reflections about the figure of the caregiver for society, health and education professionals, as well as for the families themselves. The planning, implementation, and incorporation of an intervention policy and guidelines must be considered in order to satisfy the physical, emotional, social, and financial needs of informal caregivers.

\section{CONCLUSIONS}

In the present study, there was a low general burden among caregivers of stroke victims and reduced averages in almost all items on the BCOS scale, except in the relationship of affection, friendship, love, loyalty, and protection with the care target. In the comparison test between different groups, BCOS was associated with gender and duration of caregiving, demonstrating a greater burden on female caregivers and on individuals who have cared for longer.

Informal caregivers have a hard but significant job in rehabilitation, social integration, and motivation for the person in their care. However, it is difficult to provide qualified care when experiencing negative changes in life. Therefore, it is important to assess the perception of the impact that the provision of care has on the caregiver's life.

\section{REFERENCES}

1. Pelicioni MCX, Novaes MM, Peres ASC, Souza AAL, Minelli C, Fabio SRC et al. Functional versus Nonfunctional Rehabilitation in Chronic Ischemic Stroke: evidences from a randomized functional MRI Study. Neural Plasticity. 2016;6353218. doi: 10.1155/2016/6353218

2. Ministério da Saúde (BR). DATASUS: Sistema de informações hospitalares do SUS [Internet]. 2016 [cited 2018 Aug 10]. Available from: http:// www2.datasus.gov.br/DATASUS/index.php?area $=060502$

3. Ministério da Saúde (BR). Secretaria de Atenção à Saúde. Departamento de Ações Programáticas Estratégicas. Diretrizes de atenção à reabilitação da pessoa com acidente vascular cerebral. Brasília: Ministério da Saúde, 2013.

4. Araújo JS, Silva SED, Santana ME, Santos LS, Sousa RF, Conceição VM, et al. The parallel side of caring unveiled by caregivers of patients sickened after stroke. Rev Bras Cienc Saúde [Internet]. 2014[cited 2018 Aug 10];18(2):109-14. Available from: https://pesquisa.bvsalud.org/ portal/resource/pt/lil-796536

5. Bakas T, Jessuo Nm, McLennon SM, Habermann B, Weaver MT, Morrison G. Tracking patterns of needs during a telephone follow-up program for family caregivers of persons with stroke. Disabil Rehabil. 2016;38(18):1780-90. doi: 10.3109/09638288.2015.1107767

6. Loureiro LSN, Pereira MA, Fernandes MGM, Oliveira JS. Perception of nurses on the tension of the caregiver's role. Rev Baiana Enferm. 2015;29(2):164-71. doi: 10.18471/rbe.v29i2.12596

7. Dunbar SB, Khanjou OA, Bakas T, Hunt G, Kirch RA, Leib AR, et al. Projected costs of informal caregiving for cardiovascular disease: 2015 to 2035. Circulation. 2018;137(19):e558-e577. doi: 10.1161/CIR.0000000000000570

8. Pucciarelli G, Vellone E, Savini S, Simeone S, Ausili D, Alvaro R et al. Roles of changing physical function and caregiver burden on quality of life in stroke a longitudinal dyadic analysis. Stroke. 2017;48(3):733-9. doi: 10.1161/STROKEAHA.116.014989

9. McLennon SM, Bakas T, Jessup NM, Habermann B, Weaver MT. Task difficulty and life changes among stroke family caregivers relationship to depressive symptoms. Arch Phys Med Rehabil. 2014;95(12):2484-90. doi: 10.1016/j.apmr.2014.04.028

10. Roth DL, Fredman L, Haley WE. Informal caregiving and its impact on health: a reappraisal from population-based studies. Gerontologist. 2015;55(2):309-19. doi: 10.1093/geront/gnu177

11. Young ME, Lutz BJ, Creasy KR, Cox KJ, Martz C. Comprehensive assessment of family caregivers of stroke survivors during inpatient rehabilitation. Disabil Rehabil 2014;36(22):1892-1902. doi: 10.3109/09638288.2014.881565

12. Fernandes MGM, Garcia TR. Determinatives of Family caregiver's tension while caring the dependente elderly. Rev Bras Enferm. 2009;62(1):57-63. doi: 10.1590/S0034-71672009000100009

13. Loureiro LSN, Fernandes MGM, Nóbrega MML, Rodrigues RAP. Overburden on elderly's family caregivers: association with characteristics of the elderly and care demand. Rev Bras Enferm. 2014;67(2):227-32. doi: 10.5935/0034-7167.20140030

14. Costa TF, Costa KNFM, Fernandes MGM, Martins KP, Brito SS. Quality of life of caregivers for patients of cerebrovascular accidents: association of (socio-demographic) characteristics and burden. Rev Esc Enferm USP. 2015; 49(2):243-50. doi: 10.1590/S0080-623420150000200009 
15. Lee KC, Yiin JJ, Lin PC, Lu SH. Sleep disturbances and related factors among family caregivers of patients with advanced cancer. PsychoOncology. 2017;24(12):1632-38. doi: 10.1002/pon.3816

16. Tsai PC, Yip PK, Tai JJ, Lou MF. Needs of family caregivers of stroke patients: a longitudinal study of caregivers' perspectives. Patient Prefer Adherence. 2015;9:449-57. doi: 10.2147/PPA.S77713

17. Cameron Jl, Naglie G, Silver FL, Gignac MA. Stroke family caregivers' support needs change across the care continuum: a qualitative study using the timing it right framework. Disabil Rehabil. 2013;35(4):315-24. doi: 10.3109/09638288.2012.691937

18. Caro CC, Mendes PV, Costa JD, Nock LJ, Cruz DM. Independence and cognition post-stroke and its relationship to burden and quality of life of family caregivers. Top Stroke Rehabil. 2017;24(3):194-9. doi: 10.1080/10749357.2016.1234224

19. Adelman RD, Tmanova LL, Delgado D, Dion S, Lachs MS. Caregiver burden: a clinical review. JAMA. 2014;311(10):1052-60. doi: 10.1001/ jama.2014.304

20. Fernandes MGM, Garcia TR. Conceptual structure of the family caregivers of the dependent elderly's tension. Rev Eletr Enf. 2009;11(3):46976. Available from: http://www.fen.ufg.br/revista/v11/n3/v11n3a02.htm

21. Bakas T, Champion V, Perkins SM, Farran CJ, Williams LS. Psychometric testing of the revised 15-item Bakas Caregiving Outcomes Scale. Nurs Res. 2006;55(5):346-55. Available from: https://insights.ovid.com/pubmed?pmid=16980835

22. Bakas T, Champion V. Development and psychometric testing of the Bakas Caregiving Outcomes Scale. Appl Nurs Res. 1999;48(5):250-9. Available from: https://insights.ovid.com/pubmed?pmid=10494909

23. Fayers PM, Machin D. Quality of life. The assessment, analysis, and interpretation of patient-reported outcomes. 2. ed. Chichester: England John Wiley; 2007.

24. Oviedo HC, Campo-Arias A. Aproximación al uso del coeficiente alfa de Cronbach. Revista Colombiana de Psiquiatria. 2005;XXXIV(4):572-80. Available from: http://www.scielo.org.co/pdf/rcp/v34n4/v34n4a09.pdf

25. Govina O, Kotronoulas G, Mystakidou K, Giannakopoulou M, Galanos A, Patiraki E. Validation of the revised Bakas Caregiving Outcomes Scale in Greek caregivers of patients with advanced cancer receiving palliative radiotherapy. Support Care Cancer. 2013;21(5):1395-404. doi: 10.1007/s00520-012-1681-7

26. Denno MS, Gillard PJ, Graham GD, DiBonaventura MD, Goren A, Varon SF, et al. Anxiety and depression associated with caregiver burden in caregivers of stroke survivors with spasticity. Arch Phys Med Rehabil. 2014;94(9):1731-6. doi: 10.1016/j.apmr.2013.03.014

27. Kim D. Relationships between caregiving stress, depression, and self-esteem in family caregivers of adults with disability. Occup Ther Int. 2017;2017:1686143. doi: 10.1155/2017/1686143

28. Chung ML, Bakas T, Plue LD, Williams LS. Effects of self-esteem, optimism, and perceived control on depressive symptoms in stroke survivorspouse dyads. J Cardiovasc Nurs. 2016;31(2):E8-E16. doi: 10.1097/JCN.0000000000000232

29. Mroz EL, Poulin MJ, Grant PC, Depner RM, Breier J, Byrwa DJ et al. Caregiver self-esteem as a predictor of patient relationship satisfaction: a longitudinal study. J Palliat Med. 2018;21(3):376-9. doi: 10.1089/jpm.2017.0231

30. Gonzalez C, Bakas T. Factors associated with stroke survivor behaviors as identified by family caregivers. Rehabil Nurs. 2013;38(4):202-11. doi: $10.1002 / \mathrm{rnj} .85$

31. Katbamna S, Manning L, Mistri A, Johnson M, Robinson T. Balancing satisfaction and stress: carer burden among White and British Asian Indian carers of stroke survivors. Ethn Health. 2017;22(4):425-41. doi: 10.1080/13557858.2016.1244740

32. Barbic SP, Mayo NE, White Cl, Bartlett SJ. Emotional vitality in family caregivers: Content validation of a theoretical framework. Qual Life Res. 2014;23(10):2865-72. doi: 10.1007/s11136-014-0718-4

33. Van Dongen I, Josephsson S, Ekstam L. Changes in daily occupations and the meaning of work for three women caring for relatives poststroke. Scand J Occup Ther. 2014;21(5):348-58. doi: 10.3109/11038128.2014.903995

34. Bastawrous M, Gignac MA, Kapral MK, Cameron Jl. Adult daughters providing post-stroke care to a parent: a qualitative study of the impact that role overload has on lifestyle, participation and family relationships. Clin Rehabil. 2015;29(6):59-600. doi: 10.1177/0269215514552035

35. Quinn K, Murray C, Malone C. Spousal experiences of coping with and adapting to caregiving for a partner who has a stroke: a metasynthesis of qualitative research. Disabil Rehabil. 2014;36(3):185-98. doi: 10.3109/09638288.2013.783630

36. Pesantes MA, Brandt LR, Ipince A, Miranda JJ, Diez-Canseco F. An exploration into caring for a stroke-survivor in Lima, Peru: Emotional impact, stress factors, coping mechanisms and unmet needs of informal caregivers. eNeurological Sci. 2017;6:33-50. doi: 10.1016/j. ensci.2016.11.004

37. Ain QUI, Dar NZ, Ahmad A, Munzar S, Yousafzai AW. Caregiver stress in troke survivor: data from a tertiary care hospital - a cross sectional survey. BMC Psychol. 2014;2(1):49. doi: 10.1186/s40359-014-0049-9

38. Costa TF, Costa KNFM, Martins KP, Fernandes MGM, Brito SS. Burden over Family caregivers of elderly people with stroke. Esc Anna Nery. 2015;19(2):350-5. doi: 10.5935/1414-8145.20150048

39. Jessup NM, Bakas T, McLennon SM, Weaver MT. Are there gender, racial, or relationship differences in caregiver task difficulty, depressive symptoms, and life changes among stroke family caregivers? Brain Inj. 2015;29(1):17-24. doi: 10.3109/02699052.2014.947631

40. Loh AZ, Tan JS, Zhang MW, Ho RC. The global prevalence of anxiety and depressive symptoms among caregivers of stroke survivors. J Am Med Dir Assoc. 2017;18(2):111-6. doi: 10.1016/j.jamda.2016.08.014 
41. Menon B, Salini P, Habeeba K, Conjeevaram J, Munisusmitha K. Female caregivers and stroke severity determines caregiver stress in stroke patients. Ann Indian Acad Neurol. 2017;20(4):418-24. doi: 10.4103/aian.AIAN_203_17

42. Akosile CO, Banjo TO, Okoye EC, Ibikunle PO, Odole AC. Informal caregiving burden and perceived social support in an acute stroke care facility. Health Qual Life Outcomes. 2018;16(1):57. doi: 10.1186/s12955-018-0885-z

43. Jeong YG, Myong JP, Koo JW. The modifying role of caregiver burden on predictors of quality of life of caregivers of hospitalized chronic stroke patients. Disabil Health J. 2015;8(8):619-25. doi: 10.1016/j.dhjo.2015.05.005

44. Jellema S, Wijnen MAM, Steultjens EMJ, Nijhuis-van der Sanden MWG, Van der Sande R. Valued activities and informal caregiving in stroke: a scoping review. Disabil Rehabil. 2018;17:1-12. doi: 10.1080/09638288.2018.1460625

45. Jeong YG, Jeong YJ, Kim WC, Kim JS. The mediating effect of caregiver burden on the caregivers' quality of life. J Phys Ther Sci. 2015;27(5):1543-7. doi: 10.1589/jpts.27.1543

46. Han Y, Liu Y, Zhang X, Tam W, Mao J, Lopez V. Chinese family caregivers of stroke survivors: Determinants of caregiving burden within the first six months. J Clin Nurs. 2017;26(23-24):4558-66. doi: 10.1111/jocn.13793

47. Byun E, Evans LK. Concept analysis of burden in caregivers of stroke survivors during the Early poststroke period. Clin Nurs Res. 2014;24(5):468-86. doi: 10.1177/1054773814537060 